\title{
An ethno-pharmacological study of plants used for traditional medication in Tangail district, Bangladesh
}

\author{
A. H. M. Mahmudur Rahman ${ }^{1}$, Mahmoud Rafieian-Kopaei²
}

${ }^{1}$ Pharmacy Student, Department of Pharmaceutical sciences, North South University, Dhaka, Bangladesh

${ }^{2} \mathrm{PhD}$ of Pharmacology, Professor, Medical Plants, Research Center, Shahrekord University of Medical Sciences, Shahrekord, Iran

\section{Type of article: Original}

\begin{abstract}
Background: In Bangladesh, folk medicinal practitioners are called "Kaviraj" and are consulted for treatment of various ailments by a large part of the rural and urban population. There are some previous studies conducted in the Tangail district of Bangladesh about medicinal plants, but there is no relevant information about this aspect in some parts of this district.

Aim: To conduct an ethno-pharmacological survey among the "Kaviraj" of two upazilas (regions) in Tangail district, namely Tangail Sadar Upazila and Nagarpur Upazila, to identify the trouble-free formulations of medicinal plants for various diseases used by the folk medicine practitioners on or after other forms of medical practices.

Methods: A guided field-walk survey was carried out employing a local guide and asking local people about practicing "Kaviraj"; four of the "Kaviraj" convened and after receiving permission from the "Kaviraj", interviews were conducted through focused group discussion.

Results: It was observed that the "Kaviraj" of the two upazilas used a total of 25 plants distributed into 20 families for healing of various diseases. In most of the cases, leaves were the key part of most of the plants used for treatment. Plants were mainly used for treating gastrointestinal tract disorders, fever, constipation, and diarrhea, and indigestion, loss of appetite, pain and skin disorders. "Kaviraj" also treat complicated diseases such as tuberculosis, hypertension, sexual disorders, infections, urinary problems, hepatic disorders, pneumonia, stomach stones, diabetes, swellings, debility, kidney problems, tumor, vitamin $\mathrm{C}$ deficiency and poisoning by using medicinal plants

Conclusion: For a country such as Bangladesh, and particularly the district studied, medicinal plants are essential assets and have a major role in people's health care structure. Also, appropriate research should be conducted for using these medicinal plants in possible new drug designs as well as many other pharmaceutical benefits.
\end{abstract}

Keywords: Medicinal plants, Tangail, Bangladesh, Pharmacology

\section{Introduction}

Bangladesh is a South Asian country which exists on the Bay of Bengal with an area of approximately $144,000 \mathrm{~km}^{2}$ and with a population of more than 160 million. It is a developing country with a mainstream of rural population who lack access to current healthcare. Otherwise, they cannot afford the price of allopathic drugs. A large section of the population is beneath the poverty level (1-5). As a result, malnutrition and poor hygienic conditions of living are widespread. The prime health care of the rural population and a considerable subdivision of the urban population is provided by traditional medicinal practitioners, who possess significant expertise in medicinal plants (6-9). Not only in Bangladesh but also in many countries worldwide, traditional medicinal practices form a major part of healthcare prerequisite even in these days of allopathic medicine. In Bangladesh, "Kaviraj" is a common word which is used for folk medicinal practitioners of both rural and urban areas (10-14). Still, there are lots of rural patients in Bangladesh who do not believe in allopathic medicinal treatment. Overall, most of the patients are poor but some

\section{Corresponding author:}

Professor Dr. Mahmoud Rafieian-Kopaei, Medical Plants, Research Center, Shahrekord University of Medical Sciences, Shahrekord, Iran. Tel: +989131811842, Fax:+983833330709, Email: rafieian@yahoo.com

Received: December 17, 2016, Accepted: May 15, 2017, Published: July 2017

iThenticate screening: March 21, 2017, English editing: June 02, 2017, Quality control: June 12, 2017

(C) 2017 The Authors. This is an open access article under the terms of the Creative Commons Attribution-NonCommercialNoDerivs License, which permits use and distribution in any medium, provided the original work is properly cited, the use is non-commercial and no modifications or adaptations are made. 
people from the affluent classes also seek its benefits. Medicinal plants or plant parts are used to construct easy formulations, which apply in support of treatment. Formulations consist of crushing the whole plant or plant components which may then be administered depending on the diseases. Each "Kaviraj" tends to keep his or her acquaintance of medicinal plants within the family which is passed on from generation to generation. Over time, this knowledge has become sole to the Kaviraj. The medicinal plants utilized by the "Kaviraj" vary significantly between "Kaviraj" of different regions or tribes (15-22). Hence, recording the knowledge of these experts is essential. A plant can be used for several diseases of a dissimilar nature. A plant may be administered in the cooked appearance in some extraordinary cases. Amalgamation of plants may also have effect if the main plant used for healing has sideeffects. In this case, another plant may be added to neutralize the side effects. Some plants are used in mixing with oils during topical uses. The use of medicinal plants to cure various ailments goes back thousands of years and is extended over all regions of the world occupied by human beings. Moreover, even nowadays numerous modern drugs have their origins in the plants used by aboriginal people. About $64 \%$ of the total global population remain reliant on traditional medicine for their health care requirements (23-28). As an element of the Indian subcontinent, Bangladesh has a long history of using medicinal plants intended for curing diseases. Leaf extracts of some medicinal plants demonstrate notable levels of total phenolics and flavonoids and have demonstrated high-quality anti-oxidant activities. Many studies have suggested that the medicinal plants can also serve the purpose of a food supplement for a greater number of people (29-36). On the whole, there is a rising realization concerning medicinal plants that a number of them can serve as useful foods and so can be utilized both as nutrients and in addition to medicine. Ever since the tribal population of Bangladesh, in their thickly forested environment lacked right of access to modern medicinal facilities, the medicinal plants formed a key mode of health-care for treating their occasionally infective medical conditions (37-40). Bangladesh has lots of upazilas and villages where at least one folk practitioner will be found. They have served the rural people since primordial times and have gained a special place in the heart of rural people. Bangladesh has more than 5,000 floral types (14-46). To obtain an inclusive depiction of the flora of Bangladesh, which can be classified as medicinal plants; many researchers are conducting surveys among "Kaviraj" of individual villages and tribes. To get a greater viewpoint on the medicinal plants of Tangail district situated in the central part of Bangladesh, the present survey was conducted in the middle of the "Kaviraj" of two upazilas of this district, to find a comprehensive picture of the medicinal plants in this district. It is also imperative to have a database of the medicinal plants of the country not only to guide future scientific research but also for protection of important plants, which are swiftly becoming rare due to lack of such a database.

\section{Material and Methods}

It was a guided field-walk survey and was conducted in two upazilas, namely Tangail Sadar Upazila and Nagarpur Upazila of Tangail district, in which most of the villagers (where Tangail Sadar Upazila has 273 villages and Nagarpur Upazila has 243 villages) are small business holders. A guide was managed initially (Mr. Shahadat) and local people were asked about the details of practicing "Kaviraj" and four "Kaviraj" convened for interview, namely Mr. Rashun Kha, Mr. Hazrat Ali, Mr. Kuddos Molla and Mr. Anondo Das. Interviews were conducted in Bengali after receiving permission from the four "Kaviraj" to start the survey and subsequently a focused group discussion was conducted. They discussed medicinal plants and gave explanations of their local names and uses. All information obtained was cross-checked with the "Kaviraj" the following day, the English names of the plants were translated by the guide, and details of the plants were collected from the "Medicinal Plants Database of Bangladesh". As participation was voluntary, no ethical permission was needed. Data were collected and transferred into the Microsoft Excel Spreadsheet 2010 (Microsoft Corp., USA) and demonstration of the data was performed as table and percentage.

\section{Results}

In the focused group discussion, it was learned that the "Kaviraj" of the two upazilas usually use 25 plants circulated into 20 families for treatment purposes. Some basic information about those plants is presented in Table 1. It was found that these plants are from twenty families according to classification where five families have two plants each and the other fifteen families, one plant each. It was also revealed that they use leaf and root in $8 \%$ of cases, fruits in $8 \%$, leaf in $28 \%$, leaf and fruit in $20 \%$, leaf and stem in $8 \%$, leaf and wood in $4 \%$, only root in $4 \%$ and only stem in $12 \%$ of cases. In $8 \%$ of cases, they use whole plants. They also use a combination of medicinal plants in some specific cases. Plants are used for treating simple to complicated diseases. In Table 2, the reasons of using the medicinal plants are noted. 
Table 1. Basic Information about medicinal plants used in Tangail

\begin{tabular}{|c|c|c|c|c|}
\hline Scientific Name & English Names & Local Name & Family Name & Part consumed \\
\hline Achyranthes aspera L. & Chaff-flower & Udvid nagra & Amaranthaceae & Leaf and root \\
\hline Amaranthus spinosus L. & Spiny amaranth & Khuira kanta & Amaranthaceae & Leaf and stem \\
\hline Justicia adhatoda L. & Malabar nut & Kalo durba & Acanthaceae & Stem \\
\hline Centella asiatica (L.) Urb. & Centella & Thankuni & Apiaceae & Leaf \\
\hline Calotropis gigantea (L.) Ait.f. & Crown flower & Akondo & Asclepiadaceae & Leaf \\
\hline Alstonia scholaris (L.) R.Br. & Blackboard tree & Chaitan & Apocynaceae & Leaf and wood \\
\hline Ageratum conyzoides L. & Billygoat-weed & Shial moti & Asteraceae & Leaf \\
\hline Xanthium indicum J. Koenig ex Roxb. & Woolgarie bur & Ghagra kanta & Asteraceae & Leaf \\
\hline Opuntia dillenii (Ker-Gawl.) Haw. & Cactus & Moni raaj & Cactaceae & Whole plant \\
\hline Kalanchoe pinnata (Lam.) Pers. & American Life Plant & Pathorkuchi & Crassulaceae & Whole plant \\
\hline Coccinia grandis (L.) J. Voigt & Scarlet gourd & Telakuchi & Cucurbitaceae & Leaf and fruit \\
\hline Cyperus rotundus L. & Purple nut sedge & Vadal & Cyperaceae & Stem \\
\hline Dioscorea bulbifera L. & Yam & Goiza alu & Dioscoreaceae & Fruit \\
\hline Euphorbia tirucalli L. & Aveloz & Dudh kora & Euphorbiaceae & Leaf and stem \\
\hline Clerodendrum viscosum Vent. & Hill glory bower & Vita & Lamiaceae & Leaf \\
\hline Leucas aspera (Willd.) Link & Common Leucas & Dondo kolosh & Lamiaceae & Stem \\
\hline Azadirachta indica A. Juss. & Indian Lilac & Neem & Meliaceae & Leaf \\
\hline Psidium guajava L. & Guava & Piyara & Myrtaceae & Leaf and fruit \\
\hline $\begin{array}{l}\text { Syzygium malaccense (L.) Merr. \& L. M. } \\
\text { Perry }\end{array}$ & Malay rose apple & Jamrul & Myrtaceae & Root \\
\hline Ziziphus jujuba Mill. & Jujube & Boroi & Rhamnaceae & Leaf and fruit \\
\hline Citrus acida Roxb. & Kumquats & Lebu & Rutaceae & Leaf and fruit \\
\hline Scoparia dulcis L. & Licorice weed & Korat chini & Scrophulariaceae & Leaf and root \\
\hline Smilax china L. & China root & Kumira kanta & Smilacaceae & Leaf \\
\hline Datura metel L. & Metel & Kalo dhutura & Solanaceae & Leaf and fruit \\
\hline Solanum surattense Burm.f. & Febrifuge plant & Choroi baegun & Solanaceae & Fruit \\
\hline
\end{tabular}

Table 2. Reasons behind using medicinal plant in Tangail

\begin{tabular}{|l|l|}
\hline Scientific Name & Justification of use \\
\hline Achyranthes aspera L. & Night-time incontinence and constipation \\
\hline Amaranthus spinosus L. & Jaundice. \\
\hline Justicia adhatoda L. & Tuberculosis. \\
\hline Centella asiatica (L.) Urb. & Fever and pain. \\
\hline Calotropis gigantea (L.) Ait.f. & Pneumonia and severe pain. \\
\hline Alstonia scholaris (L.) R.Br. & Restlessness in cows \\
\hline Ageratum conyzoides L. & To speed up delivery in cows. \\
\hline Xanthium indicum J. Koenig ex Roxb. & Skin diseases. \\
\hline Opuntia dillenii (Ker-Gawl.) Haw. & To maintain the body in good health. \\
\hline Kalanchoe pinnata (Lam.) Pers. & Stone formation in stomach. \\
\hline Coccinia grandis (L.) J. Voigt & Diabetes and swellings. \\
\hline Cyperus rotundus L. & Pain. \\
\hline Dioscorea bulbifera L. & To boost strength. \\
\hline Euphorbia tirucalli L. & To increase milk production in cows. \\
\hline Clerodendrum viscosum Vent. & Pain in body and blood purifier. \\
\hline Leucas aspera (Willd.) Link & Diarrhea, blood purifier and loss of appetite indigestion. \\
\hline Azadirachta indica A. Juss. & Diarrhea, blood purifier and indigestion. \\
\hline Psidium guajava L. & Diarrhea and debility. \\
\hline Syzygium malaccense (L.) Merr. \& L. M. Perry & Helminthiasis. \\
\hline Ziziphus jujuba Mill. & Hypertension. \\
\hline Citrus acida Roxb. & Facial scars and spots and vitamin C deficiency. \\
\hline Scoparia dulcis L. & Urinary problems. \\
\hline Smilax china L. & Kidney and hepatic problems. \\
\hline Datura metel L. & Antidote to poisoning. \\
\hline Solanum surattense Burm.f. & Tumor in humans and swelling of throat in cattle. \\
\hline
\end{tabular}




\section{Discussion}

This study was totally focused on medicinal plants of Tangail district. The number of plants used for healing of any disease normally indicates the prevalence of the disruption or ailment among the populace treated. It is found that a particular plant part may be used for curing more than one ailment (47-50). These folk practitioners are treating gastrointestinal tract disorders, fever, constipation, and diarrhea, and indigestion, loss of appetite, pain and skin disorders. "Kaviraj" also treat complicated diseases such as tuberculosis, hypertension, sexual disorders, infections, urinary problems, hepatic disorders, pneumonia, stomach stones, diabetes, swellings, debility, kidney problems, tumor, vitamin $\mathrm{C}$ deficiency, and poisoning by using medicinal plants. Cattle are also being treated by them. Some of the plants showed good pharmacologic effects on rats in some previously done studies. But some plants are still untested pharmacologically. Overall, those medicinal plants used by the Kavirajes in two upazilas of Tangail district, Bangladesh possess substantial potential in containing constituents (51). As herbs are natural products, they are usually free of side effects, comparatively safe and eco-friendly as well as locally available. Pharmaceutical companies are conducting their research on medicinal plants along with using them as a source of medicine. Botanists, pharmacologists, microbiologists, and natural-product chemists are combing the earth for phytochemicals with leads that could be developed for treatment of assorted diseases. In truth, according to the World Health Organization, roughly $25 \%$ of modern drugs used in the United States have been derived from plants. As we mentioned earlier, Bangladesh has over 5000 floral species, of which 500-600 are generally considered medicinal plants (52). The use of Azadirachta indica has been reported for treatment of jaundice in other districts of Bangladesh, which has been found in some previous studies. The tribal people of North Maharashtra, India use the plant against jaundice. Different uses of the same plant species can also be established in the scientific literature for various communities at various localities in India and other South Asian countries $(53,54)$. It is predictable that scientific studies conducted with the plants reported, may guide us to discovery of more efficacious drugs for treatment of this endemic problem. This survey will also help us to preserve the important rare species of medicinal plants. Regarding the study limitations, the only limitation of this study was that the number of participating folk practitioners was only four as most of them were not interested in sharing their theory.

\section{Conclusions}

The ethno-medicinal exercise of plant species was recognized in the study area for healing of human and veterinary diseases. The data accessible in this paper form a basis for further ethno-pharmacological research in this district especially in studies dealing with effectiveness, amount, superiority and toxicology. In preparation of profit-making indigenous-based pharmaceuticals, those plants found empirically to be mainly efficient and can be used. Therefore, a thorough certification of the medicinal plant uses that are obtainable in Bangladesh is important. The findings of the present survey propose that the medicinal plants that have been reported to be used for different types of diseases may be scientifically studied for discovering relevant pharmacological effects in order to manufacture successful drugs designed with fewer side effects.

\section{Acknowledgments:}

The authors acknowledged Mr. Rashun Kha, Mr. Hazrat Ali, Mr. Kuddos Molla and Mr. Anondo Das for their kind support.

\section{Conflict of Interest:}

There is no conflict of interest to be declared.

\section{Authors' contributions:}

Both authors contributed to this project and article equally. Both authors read and approved the final manuscript.

\section{References:}

1) Rahmatullah, M., A.K. Das, M.A.H. Mollik, R. Jahan, M. Khan, T. Rahman et al, An Ethnomedicinal Survey of Dhamrai Sub-district in Dhaka District, Bangladesh. American Eurasian Journal of Sustainable Agriculture, 2009; 3(4): 881-8.

2) Nawaz, A.H.M.M., M. Hossain, M. Karim, M. Khan, R. Jahan and M. Rahmatullah, An ethnobotanical survey of Rajshahi district in Rajshahi division, Bangladesh. American Eurasian Journal of Sustainable Agriculture, 2009; 3(2): 143-50.

3) Hossan, M.S., A. Hanif, B. Agarwala, M.S. Sarwar, M. Karim, M.T. Rahman, et al. Traditional use of medicinal plants in Bangladesh to treat urinary tract infections and sexually transmitted diseases. Ethnobotany Research and Applications, 2010; (8): 61-74. https://doi.org/10.17348/era.8.0.61-74 
4) Rahmatullah, M., D. Ferdausi, M.A.H. Mollik, M.N.K. Azam, M.T. Rahman and R. Jahan, Ethnomedicinal Survey of Bheramara Area in Kushtia District, Bangladesh. American Eurasian Journal of Sustainable Agriculture, 2009; 3(3): 534-41. https://doi.org/10.4314/ajtcam.v7i2.50859

5) Rahmatullah, M., D. Ferdausi, M.A.H. Mollik, R. Jahan, M.H. Chowdhury and W.M. Haque, A Survey of Medicinal Plants used by Kavirajes of Chalna area, Khulna District, Bangladesh. African Journal of Traditional, Complementary and Alternative Medicines, 2010; 7(2): 91-7.

6) Hanif, A., Md. Shahadat Hossan, Md. Manzurul Kadir Mia, Mohammad Jahirul Islam, Rownak Jahan and Mohammed Rahmatullah, Ethnobotanical survey of the Rakhain tribe inhabiting the Chittagong Hill Tracts region of Bangladesh. American Eurasian Journal of Sustainable Agriculture, 2009; 3(2): 172-80.

7) Hossan, Md. Shahadat, Abu Hanif, Mujib Khan, Sazzadul Bari, Rownak Jahan and Mohammed Rahmatullah. Ethnobotanical survey of the Tripura tribe of Bangladesh. American Eurasian Journal of Sustainable Agriculture, 2009; 3(2): 253-61.

8) Rahmatullah, M., A. Noman, M.S. Hossan, M.H. Rashid, T. Rahman, M.H. Chowdhury and R. Jahan, A survey of medicinal plants in two areas of Dinajpur district, Bangladesh including plants which can be used as functional foods. American Eurasian Journal of Sustainable Agriculture, 2009; 3(4): 862-76.

9) Rahmatullah, M., M.A.H. Mollik, A.T.M.A. Azam, M.R. Islam, M.A.M. Chowdhury, R. Jahan, M.H. Chowdhury and T. Rahman, Ethnobotanical Survey of the Santal tribe residing in Thakurgaon District, Bangladesh. American Eurasian Journal of Sustainable Agriculture, 2009; 3(4): 889-98.

10) Rahmatullah, M., I.J. Mukti, A.K.M.F. Haque, M.A.H. Mollik, K. Parvin, R. Jahan, et al. An Ethnobotanical Survey and Pharmacological Evaluation of Medicinal Plants used by the Garo Tribal Community living in Netrakona district, Bangladesh. Advances in Natural and Applied Sciences, 2009; 3(3): 402-18.

11) Martin, G.J., Ethnobotany: a 'People and Plants' Conservation Manual, Chapman and Hall, London, 1995: 268. https://doi.org/10.1007/978-1-4615-2496-0

12) Rahmatullah, M., M.S. Hossan, A. Hanif, P. Roy, R. Jahan, M. Khan, et al. Ethnomedicinal Applications of Plants by the Traditional Healers of the Marma Tribe of Naikhongchhari, Bandarban District, Bangladesh. Advances in Natural and Applied Sciences, 2009; 3(3): 392-401.

13) Maundu, P. Methodology for collecting and sharing indigenous knowledge: a case study. Indigenous Knowledge and Development Monitor. 1995; 3: 3-5.

14) Barry, V.C., M.L. Conalty, H.J. Rylance and F.R. Smith, Antitubercular effect of an extract of Adhatoda vasica. Nature, 1955; 176: 119-20. https://doi.org/10.1038/176119a0, PMid: 13244629

15) Gupta, K.C. and I.C. Chopra. Anti-tubercular action of Adhatoda vasica (N.O.acanthacea). Indian Journal of Medical Research, 1954; 42: 355-8. PMid: 13210983

16) Grange, J.M. and N.J. Snell. Activity of bromhexine and ambroxol, semi-synthetic derivatives of vasicine from the Indian shrub Adhatoda vasica, against Mycobacterium tuberculosis in vitro. Journal of Ethnopharmacology, 1996; 50: 49-53. https://doi.org/10.1016/0378-8741(95)01331-8

17) Gupta, R., B. Thakur, P. Singh, H.B. Singh, V.D. Sharma, V.M. Katoch et al. Antituberculosis activity of selected medicinal plants against multi-drug resistant Mycobacterium tuberculosis isolates. Indian Journal of Medical Research, 2010; 131: 809-13. PMid: 20571171

18) Zeashan, H., G. Amresh, S. Singh and C.V. Rao, Hepatoprotective activity of Amaranthus spinosus in experimental animals. Food and Chemical Toxicology, 2008; 46: 3417-21. https://doi.org/10.1016/j.fct.2008.08.013, PMid: 18783728

19) Lin, S.C., C.C. Lin, Y.H. Lin, S. Supriyatna and S.L. Pan, The protective effect of Alstonia scholaris R. Br. on hepatotoxin-induced acute liver damage. The American Journal of Chinese Medicine, 1996; 24: 153-64. https://doi.org/10.1142/S0192415X96000207, PMid: 8874672

20) Ojewole, J.A.O., E.O. Awe and W.D.H. Chiwororo, Antidiarrhoeal activity of Psidium guajava Linn. (Myrtaceae) leaf aqueous extract in rodents. Journal of Smooth Muscle Research, 2008; 44: 195-207. https://doi.org/10.1540/jsmr.44.195, PMid: 19234374

21) Soares, P.M., S.R. Lima, S.G. Matos, M.M. Andrade, M.C. Patrocínio, C.D. de Freitas. Assreuy and S.M. Vasconcelos, Antinociceptive activity of Calotropis procera latex in mice. Journal of Ethnopharmacology, 2005; 99: 125-9. https://doi.org/10.1016/j.jep.2005.02.010, PMid: 15848031

22) Saxena, R.S., B. Gupta, K.K. Saxena, V.K. Srivastava and D.N. Prasad. Analgesic, antipyretic and ulcerogenic activity of Nyctanthes arbor tristis leaf extract. Journal of Ethnopharmacology, 1987, 19: 193 200. https://doi.org/10.1016/0378-8741(87)90041-9 
23) Birdi, T., P. Daswani, S. Brijesh, P. Tetali, A. Natu and N. Antia. Newer insights into the mechanism of action of Psidium guajava L. leaves in infectious diarrhoea. BMC Complementary and Alternative Medicine, 2010,10: 33. https://doi.org/10.1186/1472-6882-10-33, PMid: 20584265, PMCid: PMC2911405

24) Akber, M., S. Seraj, F. Islam, D. Ferdausi, R. Ahmed, D. Nasrin, et al. A survey of medicinal plants used by the traditional medicinal practitioners of Khulna City, Bangladesh. American-Eurasian Journal of Sustainable Agriculture, 22011; 5: 177-195.

25) Azam, M.N.K., M.N. Ahmed, M.M. Rahman and M. Rahmatullah. Ethnomedicines used by the Oraon and Gor tribes of Sylhet district, Bangladesh. American-Eurasian Journal of Sustainable Agriculture, 2013;; 7: 391-402.

26) Badgujar, S.B., M.B. Patil. Ethnomedicines for jaundice used in tribal areas of North Maharashtra. Natural Product Radiance, 2008; 7: 79-81.

27) Biswas, K.R., T. Ishika, M. Rahman, A. Swarna, T. Khan, M.N. Monalisa et al. Antidiabetic plants and formulations used by folk medicinal practitioners of two villages in Narail and Chuadanga districts, Bangladesh. American-Eurasian Journal of Sustainable Agriculture, 2011a; 5: 158-167.

28) Biswas, A., W.M. Haq, M. Akber, D. Ferdausi, S. Seraj, F.I. Jahan, et al. A survey of medicinal plants used by folk medicinal practitioners of Paschim Shawra and Palordi villages of Gaurnadi Upazila in Barisal district, Bangladesh. American-Eurasian Journal of Sustainable Agriculture, 2011b; 5: 15-22.

29) Biswas, K.R., T. Khan, M.N. Monalisa, A. Swarna, T. Ishika, M. Rahman and M. et al. Medicinal plants used by folk medicinal practitioners of four adjoining villages of Narail and Jessore districts, Bangladesh. American-Eurasian Journal of Sustainable Agriculture, 2011c; 5: 23-33.

30) Biswas, B., M.Y. Arafat, M.S. Hossain, M. Sakib-uz-Zaman, Z. Khatun, M. Rahmatullah. Ethnomedicinal practices of a village folk medicinal practitioner in Faridpur District, Bangladesh. American-Eurasian Journal of Sustainable Agriculture, 2014; 8: 20-27.

31) Chowdhury, A.R., F.I. Jahan, S. Seraj, Z. Khatun, F. Jamal, S. Ahsan, R. et al. A survey of medicinal plants used by Kavirajes of Barisal town in Barisal district, Bangladesh. American-Eurasian Journal of Sustainable Agriculture, 2010; 4: 237-246.

32) Chowdhury, A.R., M. Rahmatullah. Ethnomedicinal plants for treatment of jaundice by the folk and tribal medicinal practitioners of several districts in Bangladesh and review of their scientifically reported hepatoprotective activity. American-Eurasian Journal of Sustainable Agriculture, 2012; 6: 360-370.

33) Das, P.R., M.T. Islam, A.S.M.S.B. Mahmud, M.H. Kabir, M.E. Hasan, Z. Khatun, M.M. et al. An ethnomedicinal survey conducted among the folk medicinal practitioners of three villages in Kurigram district, Bangladesh. American-Eurasian Journal of Sustainable Agriculture, 2012; 6: 85-96.

34) Ghorband, D.P., S.D. Biradar. Traditional medicines knowledge in Dharmabad taluka of Nanded district, Maharashtra, India. Indian Journal of Natural Products and Resources, 2011; 2: 498-503.

35) Gunasekaran, M., P. Balasubramanian. Ethomedicinal uses of Sthalavrikshas (temple trees) in Tamil Nadu, southern India. Ethnobotany Research \& Applications, 2012; 10: 253-268. https://doi.org/10.17348/era.10.0.253-268

36) Gupta, R., M.G. Vairale, R.R. Deshmukh, P.R. Chaudhary, S.R. Wate. Ethnomedicinal uses of some plants used by the Gond tribe of Bhandara district, Maharashtra. Indian Journal of Traditional Knowledge, 2010; 9: 713-717.

37) Haque, M.A., M.K. Shaha, S.U. Ahmed, R. Akter, H. Rahman, S. Chakravotry, A.H.M.N. et al. Use of inorganic substances in folk medicinal formulations: a case study of a folk medicinal practitioner in Tangail district, Bangladesh. American-Eurasian Journal of Sustainable Agriculture, 2011; 5: 415-423.

38) Hasan, M.M., M.E.A. Annay, M. Sintaha, H.N. Khaleque, F.A. Noor, A. Nahar, S. et al. A survey of medicinal plant usage by folk medicinal practitioners in seven villages of Ishwardi Upazilla, Pabna district, Bangladesh. American-Eurasian Journal of Sustainable Agriculture, 2010; 4: 326-333.

39) Hasan, M.E., S. Akter, N.S. Piya, P.K. Nath, U.S.R. Nova, H.R. Chowdhury, N.F. et al. Variations in selection of medicinal plants by tribal healers of the Soren clan of the Santal tribe: a study of the Santals in Rajshahi district, Bangladesh. American-Eurasian Journal of Sustainable Agriculture, 2012; 6: 315-324.

40) Hossan, M.S., P. Roy, S. Seraj, S.M. Mou, M.N. Monalisa, S. Jahan, T. et al. Ethnomedicinal knowledge among the Tongchongya tribal community of Roangchaari Upazila of Bandarban district, Bangladesh. American-Eurasian Journal of Sustainable Agriculture, 2012; 6: 349-359.

41) Islam, F., F.I. Jahan, S. Seraj, I. Malek, A.F.M.N. Sadat, M.S.A. Bhuiyan, A. et al. Variations in diseases and medicinal plant selection among folk medicinal practitioners: a case study in Jessore district, Bangladesh. American-Eurasian Journal of Sustainable Agriculture, 2011; 5: 282-291. 
42) Jahan, F.I., M.R.U. Hasan, R. Jahan, S. Seraj, A.R. Chowdhury, M.T. Islam, Z. et al. A comparison of medicinal plant usage by folk medicinal practitioners of two adjoining villages in Lalmonirhat district, Bangladesh. American-Eurasian Journal of Sustainable Agriculture, 2011; 5: 46-66.

43) Jannat, K., M. Akter, S. Sharmin, U. Rukaiya, M. Afrin, P.R. Das, M.T. et al. Ethnomedicinal practices of folk medicinal practitioners in two villages of Jamalpur district, Bangladesh. World Journal of Pharmacy and Pharmaceutical Sciences, 2015; 4: 201-211.

44) Kabir, M.H., N. Hasan, M.M. Rahman, M.A. Rahman, J.A. Khan, N.T. Hoque, M.R.Q. et al. Tribal medicine in tribes who have lost their identities: Medicinal plants of tea garden workers in Sreemangal, Maulvibazar district, Bangladesh. American-Eurasian Journal of Sustainable Agriculture,2013; 7: 251-258.

45) Khan, M.A., M.N. Hasan, N. Jahan, P.R. Das, M.T. Islam, M.S.A. Bhuiyan, S. et al. Ethnomedicinal wisdom and famine food plants of the Hajong community of Baromari village in Netrakona district of Bangladesh. American-Eurasian Journal of Sustainable Agriculture, 2012; 6: 387-397.

46) Khatun, A., M.A.A. Khan, M.A. Rahman, M.S. Akter, A. Hasan, W. Parvin, R.J. et al. Ethnomedicinal usage of plants and animals by folk medicinal practitioners of three villages in Chuadanga and Jhenaidah districts, Bangladesh. American-Eurasian Journal of Sustainable Agriculture, 2013; 7: 319-339.

47) Malek, I., N. Mia, M.E. Mustary, M.J. Hossain, S.M. Sathi, M.J. Parvez, M. et al. Medicinal plants of the Chakma community of Rangapanir Chara area of Khagrachaari district, Bangladesh. American-Eurasian Journal of Sustainable Agriculture, 2014a; 8: 59-68.

48) Malek, I., M.R. Miah, M.F. Khan, R.B.F. Awal, N. Nahar, I. Khan, S. et al. Medicinal plants of two practitioners in two Marma tribal communities of Khagrachhari District, Bangladesh. American-Eurasian Journal of Sustainable Agriculture, 2014; 8: 78-85.

49) Manikandan, S. Ethnomedicinal flora of Ivanur Panchayat in Cuddalore district, Tamil Nadu, India. International Journal of Research in Plant Science, 2013; 3: 39-46.

50) Martin, G.J.. Ethnobotany: a 'People and Plants' Conservation Manual, Chapman and Hall, London, pp: 268. 1995. https://doi.org/10.1007/978-1-4615-2496-0

51) Maundu, P. Methodology for collecting and sharing indigenous knowledge: a case study. Indigenous Knowledge and Development Monitor, 1995; 3: 3-5.

52) Mollik, M.A.H., M.S. Hossan, A.K. Paul, M.T. Rahman, R. Jahan, and M. Rahmatullah. A comparative analysis of medicinal plants used by folk medicinal healers in three districts of Bangladesh and inquiry as to mode of selection of medicinal plants. Ethnobotany Research and Applications, 2010a; 8: 195-218. https://doi.org/10.17348/era.8.0.195-218

53) Mollik, M.A.H., A.I. Hassan, T.K. Paul, M. Sintaha, H.N. Khaleque, F.A. Noor, A. et al. A survey of medicinal plant usage by folk medicinal practitioners in two villages by the Rupsha River in Bagerhat district, Bangladesh. American-Eurasian Journal of Sustainable Agriculture, 2010b; 4: 349-356.

54) Moonmoon, M., S.A. Islam, S.T.J. Bristy, M.B. Kader, S. Akhter, S.K. Pk, S.T. Ahmed, M.P. et al. Medicinal plant knowledge of a folk medicinal practitioner in Aria Bazar village, Bogra District, Bangladesh. American-Eurasian Journal of Sustainable Agriculture, 2014; 8: 124-131. 